\title{
Diatoms as Indicator Tool for Climate and Environmental Changes and Research Imperatives for Tropical Asia
}

\author{
Ajm Abdur Rouf* \\ Institute of Tropical Ecology and Biodiversity, Bangladesh
}

*Corresponding author: Ajm Abdur Rouf, Institute of Tropical Ecology and Biodiversity, Tejkunipara, Bir Uttam Ziaur Rahman Sarak Tejgaon, Bangladesh; Email: ajmrouf@gmail.com.

\section{Mini Review}

Diatoms are microscopic autotrophic algae belonging to the Bacillariophyceae class. They may be planktonic, benthic, and epiphytic or epipelic etc., found in a wide range of habitats - freshwater, marine water and oceans. Their size ranges from 2 microns to several millimeters. Due to a silicified body wall, diatoms are preserved for long epoch of time as fossil forms. The fossil evidence shows that these tiny organisms originated close to Permian-Triassic boundary 250 Mya [1] and the estimated number of extant diatom species may well be $100,000[2]$.

Diatoms play a significant role in different bio-physical processes of the Earth, which contribute to $40-45 \%$ of net primary productivity of oceans (approximately $20 \mathrm{Pg} \mathrm{C}$ $\mathrm{yr}-1 ; 1 \mathrm{Pg}=10^{15} \mathrm{~g}$ ) or almost a quarter of the carbon fixed annually on Earth by photosynthesis [3]. Beyond that, they bear the signature of past climate changes. This community is not only part of the trophic dynamics but also serve as an ecological indicator of habitat impairment, and has an important stake in biogeochemical processes related to the silica and carbon cycles of the oceans [4].

Currently, diatoms are in the lime light of various studies and research [5-7]. Diatoms are at the forefront of paleo-climate research for biological proxy development to understand the puzzles of past changes in sea level rise, salinity or temperature gradients. The mystery of their body silicification process has also lured scientists to find clues for alternative nano-patterning strategies [8]. In the meantime, over the last two decades, efforts have been made by scientists to break the puzzles of climate change from the paleo-archives through the windows of different time scales. For example Krakens project - a large multiproxy paleo-ecology project [9], SWAP (Surface Water Acidity Programme) [10]. The magnitude of work has been very in-depth, such as the Swedish development of calibrated data on diatoms from 100 lakes, and the EU regional paleo studies, where 118 lakes of member countries have been covered.

The Tropical Asia region has some uniqueness which could be more relevant to climate change studies. These specialities or uniqueness of this region stems from being the home of the great Himalayas, with the highest global mountain peak of Everest, showered with two monsoons, prone to tropical cyclones sourced from the Bay of Bengal, north Pacific Ocean and South China Sea, rich with six biodiversity hotspots, and two largest river and delta systems of the world - Brahmaputra-Meghan and Mekong. Past climate change history showed that sea level change in South China Sea was very prominent. In the Last Glacial Maximum (LGM) 20,000 years back, the Sunda shelf was fully exposed and glacio-eustatic depression and the sea level reached $\sim 120 \mathrm{~m}$; as a result of which there developed a continuous land mass called Sunda land extended from East Malaysia up to north of Borneo [11]. A major portion of Sunda shelf surroundings were exposed as land where many lakes existed before which can be called paleo lakes today.

Asian Monsoon is an important climatic system of the world where half of the world population lives [12] and 


\section{International Journal of Oceanography \& Aquaculture}

the whole socio economic activities and agriculture are fully dependant on monsoon system. The population of Tropical Asia is 1.6 billion and expected to reach 2.4 billion in 2025 [13]. A majority of the peoples' livelihood in Tropical Asia is dependent on natural resources and ecosystem services, and due to elevated dependency of the poor people on natural resources, different ecosystems are prone to various anthropogenic stresses.

Climate change and its impact will vary among the region and countries although it is recognised as a global phenomenon [14]. Climate change studies in Tropical Asia are much deficient [15]. Diatom-based climate change studies are very scant in the tropical area. Tropical Asia consists of 16 countries of south and south-east Asia and until now only some isolated and occasional paleoenvironment works have been done, but yet they are very significant to understand the regional climate change issues. For examples, fossil diatom based paleo-monsoon studies for last $600 \mathrm{~K}$ on a Kathmandu Paleolake of Nepal surface sediment diatoms relationship with modern hydrography of South China Sea [16,17], borehole sediment diatoms distribution of South China Sea $[17,18]$, and studies of Asian summer monsoon in the past for $25 \mathrm{~K}$ years through high resolution proxy datasets of this region including multi-proxy paleo-data from lakes of Thailand [18]. Considering the special features of this region, there are tremendous scopes to undertake multiproxy based paleo-environmental studies. Sea level rise is a serious problem for the south and south-east Asian countries, where diatom can be utilised for high resolution sea-level reconstruction while foraminifera may also used to complement paleo-temperature reconstruction.

The Asian monsoon region stretches from the Arabian Sea to the South China Sea. Diatoms and other biological proxies may be efficiently utilized to understand past environment and climatic conditions of this region which are relevant to foresee future climatic and environmental changes in this data deficient area. Diatom inferred salinity [19], pH, DOC, nutrients [20], and sea level rise $[21,22]$ of past centennials to Holocene or Quaternary geological time have been intensely studied in the temperate countries of the north. Similarly, a comprehensive climate science and paleo-environmental studies need to be undertaken for Tropical Asia.

Climate change studies are mainly centred in three continents Europe, North America and Australia [23], and comparatively Asian countries play marginal roles in climate science and paleo-environmental studies which is also reflected from different international programmes, such as IGBP (International Geosphere and Biosphere Programme) where Tropical Asia was not in a position to participate effectively in different core programmes, such as PAGES (Past Global Changes), due to their own weak scientific infrastructures and lack of well trained scientists. The shortcomings are also echoed in the evaluation of Tokyo-based Asian Pacific Network on climate change [25-26] which are; scarcity of scientists, science infrastructure and science funding; limited research experience of scientists; lack of monitoring data meteorological; oceanographic, and socio-economic and analytical tools; lack of skills and knowledge in relevant methods and models and constraints in depicting credible future climate scenarios and developing regional climate model (RCM).

In the end, it is the onus and responsibility of the national governments, universities, scientists, and civil societies of the countries of the Tropical Asia to combat climate change by formulating long term climate science programmes for the sake of understanding impacts and vulnerabilities of climate changes on their people, societies and economies.

\section{References}

1. Raven JA, Waite AM (2004) The evolution of silicification in diatoms: inescapable sinking and sinking as escape?. New Phytologist 162(1): 45-61.

2. Mann, David G (2005) The species concept in diatoms: Evidence for morphologically distinct, sympatric gamodemes in four epipelic species. Plant Systematics and Evolution 164: 215-237.

3. Thornton DCO (2012) Primary Production in the Ocean, Advances in Photosynthesis - Fundamental Aspects. Dr Mohammad Najafpour (Ed.), InTech, pp: 588.

4. Tréguer P (2002) Silica and the cycle of carbon in the ocean - Concise review paper. C. R. Geoscience 334: 3-11.

5. Armbrust EV, Berges JA, Bowler C, Green BR, Martinez D, et al. (2004) The genome of the diatom Thalassiosira Pseudonana: Ecology, Evolution, and Metabolism. Science 306: 79-86.

6. Falciatore A, Bowler C (2002) Revealing the molecular secrets of marine diatoms. Annu Rev Plant Biol 53: 109-130. 


\section{International Journal of Oceanography \& Aquaculture}

7. Rivera-Vilarelle M, Valdez-Velázquez LL, QuijanoScheggia SI (2018) Description of Pseudo-nitzschia cuspidatavar. manzanillensis var. nov. (Bacillariophyceae): morphology and molecular characterization of a variety from the central Mexican pacific. Diatom Research.

8. Drum RW, Gordon R (2003) Star Trek replicators and diatom nanotechnology. Trends in Biotechnology 21(8): 325-328.

9. Birks HH, Battarbee RW, Birk HJB (2000) The development of the aquatic ecosystem at Kråkenes Lake during the late-glacial and early-Holocene - a synthesis. J Paleolim 23(1): 91-114.

10. Cameron NG, Birks HJB, Jones VJ, Berge F, Catalan J, et al. (1999) Surface-sediment and epilithic diatom $\mathrm{pH}$ calibration sets for remote European mountain lakes (AL:PE Project) and their comparison with the Surface Waters Acidification Programme (SWAP) calibration set. J Paleolimonol 22(3): 291-317.

11. Bird MI, Taylor D, Hunt C (2005) Palaeoenvironments of insular Southeast Asia during the Last Glacial Period: a savanna corridor in Sundaland?. Quaternary Science Reviews 24(2021): 2228-2242.

12. Buckley BM, Fletcher R, Wang SS, Brian Zottoli B, Pottier C (2014) Monsoon extremes and society over the past millennium on mainland Southeast Asia. Quaternary Science Rev 95: 1-19.

13. IPCC Special Report on (1997) The Regional Impacts of Climate Change. An Assessment of Vulnerability, Summary for the Policy makers. A special Report of IPCC Working Group II.

14. USEPA (2018) International Climate Impacts.

15. Deb JC (2016) Assessing Species Vulnerability to Climate Change in Tropical Asia: Implications for Biodiversity Conservation and Forest Management. $\mathrm{PhD}$. Thesis. University of Quenslnd, Australia.

16. Hayashi T, Tanimura $Y$, Kuwahara $Y$, Ohno M, Mampuku M (2009). Ecological variations in diatom assemblages in the Paleo-Kathmandu Lake linked with global and Indian monsoon climate changes for the last 600,000 years. Quaternary Research 72(3): 377-387.
17. Jiang H, Zheng Y, Ran L, Seidenkrantz B (2004) Diatoms form the surface sediments of the South China Sea and their relationships with modern hydrography. Marine Micropaleontology 53(3-4): 279-292.

18. Yim WWS, Lib J (2000) Diatom preservation in an inner continental shelf borehole from the South China Sea. Journal of Asian Earth Sciences 18(4): 471-488.

19. Chabangborn A (2014) Asian monsoon over mainland Southeast Asia in the past 25000 years. (PhD. dissertation), Stockholm University, Sweden, pp: 1-65.

20. Gasse F, Barker P, Gell PA, Fritz SC, Chalil F (1997) Diatom-inferred salinity in palaeolakes: an indirect tracer of climate change. Quaternary Science Reviews 16(6): 541-563.

21. Elleggard M, Clarke AM, Reuss N, Drew S, Weckstron $\mathrm{K}$, et al. (2006) Multi-proxy evidence of long term change in ecosystem structure in a Danish marine estuary. Estuarine Coastal and Shelf Science 68(34): $567-578$.

22. Szkornik K, Gehrels WR, Kirby JR (2006) Salt-marsh diatom distributions in Ho Bugt (western Denmark) and the development of transfer function for reconstructing Holocene sea-level changes. Marine Geology 235(1-4): 137-150.

23. Horton BP, Corbett R, Culver SJ, Edwards RJ, Hillier C (2006) Modern salt-marsh diatom distributions of the outer Banks, North Carolina, and development of transfer function for high resolution reconstructions of sea level. Estuarine, Coastal and Shelf Science 69(3-4): 381-394.

24. Pacifici M, Foden WB, Visconti P, Watson JE, Butchart SH, et al. (2015) Assessing species vulnerability to climate change. Nature Climate Change 5(3): 215-224.

25. Manton MJ, Heath L, Salinger J, Stevenson LA (2011) Climate in Asia and the Pacific: A Synthesis of APN Activities, Asia-Pacific Network for Global Change Research.

26. Edwards M, Richardson AJ (2004) Impact of climate change on marine pelagic phenology and trophic mismatch. Nature 430: 881-884. 